\title{
$\nabla$
}

\section{A praia carioca, da colônia aos anos 90: uma(s) história(s)}

\author{
Patricia Farias \\ Universidade Federal Fluminense
}

\section{Introdução}

Com seus cerca de seis milhões de habitantes ${ }^{2}$, a cidade do Rio de Janeiro é considerada uma das grandes metrópoles do país. Sua identidade, tanto para aqueles que nela moram, quanto para os outros brasileiros, e mesmo para os estrangeiros que dela têm notícia, está fortemente ligada ao sentido de interação humana com a natureza. Não a toa, seus dois maiores ícones - o Corcovado e o Pão de Açúcar - apresentam uma conjugação de paisagem natural com a ação do ser humano sobre a mesma. Para além da estátua do Cristo Redentor e do teleférico, porém, uma outra paisagem salta aos olhos quando o assunto é o Rio: a praia carioca. Só que, no caso da praia, tudo parece diferente: a natureza ali reinaria absoluta, restando a seus freqüentadores 'apenas' usufruí-la. Será mesmo assim? É sabido que o ser humano, animal simbólico, vai atribuindo sentido a tudo $o$ que o rodeia, inclusive aos espaços urbanos.

Esse impulso em direção à significação do que cerca o humano, no caso da praia, se traduz numa espécie de apropriação deste espaço aos sistemas simbólicos dos grupos que com ele se relacionam. Nesse sentido, a intenção aqui é acompanhar o processo pelo qual a praia carioca vai se 'desnaturalizando', ou melhor, se 'desneutralizando', até chegar à conotação e ao mesmo tempo ao contorno físico que possui atualmente. Neste processo, tanto as idéias sobre a praia como sua conformação espacial sofreram mudanças radicais.

Examinar essas transformações significa de certa forma contar também a própria história da cidade. Aqui, entretanto, o esforço maior é no sentido de dar conta do objeto primeiro - a praia carioca -, levando-se em 
consideração o processo urbano mais amplo, carioca e brasileiro, e o panorama internacional apenas na medida em que estes se cruzarem com o objeto central deste estudo.

\section{A praia no tempo da conquista e da colônia: luta, mercado e cemitério}

Cenário do primeiro contato entre colonizador e colonizado no Brasil, a praia também representou o primeiro passo da guerra que se travou entre ambos. Primeiro espaço de encontro entre diferenças culturais e de cor, foi a praia também o primeiro espaço de luta. O litoral funcionou ainda, nesse primeiro período, como local da efetivação do processo de exploração do território recém-descoberto, através do seu uso para embarque de matérias-primas variadas para a Europa.

Nos primeiros séculos da colonização, a orla marítima passa gradativamente também a se referir àquilo que já foi dito por Gilberto Freyre em Sobrados e Mocambos (1977): um depósito de corpos de escravos mortos. É ele quem narra, com requintes cinematográficos:

"Os urubus vinham (...) pinicar os restos de comida e de bicho morto e até os corpos de negros que a Santa Casa não enterrava direito, nem na praia nem nos cemitérios (...). (...) a maré subia e lavava a imundície das praias." (1977:195)

Para Freyre, portanto, a "fidalguia" da terra se abstinha de ir à praia, e os negros eram os freqüentadores por excelência desse espaço do lixo ${ }^{3}$. É o que se deduz pela sua referência aos tigres, barris "que ficava[m] debaixo da escada dos sobrados, acumulando matéria dos urinóis para ser[em] então conduzido[s] à praia pelos negros" (1977:197).

Esta visão nada positiva da orla marítima parece casar com o que nos informa o estudo do historiador Alain Corbin a respeito do imaginário europeu sobre a praia no período anterior a 1700 . Pelo que nos narra Corbin (1989), a praia européia só será efetivamente ocupada por banhistas no século XVIII - e mesmo assim com fins terapêuticos. Antes disso, o fantasma bíblico do dilúvio universal tinha ainda força suficiente para sugerir que o mar seria o recipiente/cemitério de todos os seres que, antes do dilúvio, viviam em terra. Por isso mesmo, a maresia seria uma emanação "mefítica", maléfica para a saúde, sinal inequívoco do apodrecimento marítimo de corpos outrora viventes; ainda segundo este raciocínio, a beira-mar seria o local onde este caldo podre depositaria seus excrementos (cf. Capítulo I, op. cit.). 
Enfim, resta registrar que, se de um lado a praia no Rio de Janeiro até este período é um local de trabalho e movimento, em torno da qual se estrutura a cidade, por outro, sua representação simbólica é a de sujeira e degradação. Talvez se possa supor que o próprio status do trabalho, neste período, se ligue a esta representação simbólica, na medida em que se refere a uma época onde o maior valor residia no espaço de uma nobreza pouco afeita à lida, ou seja, no ócio como sinal de riqueza. Resta frisar ainda que a praia aqui referida é aquela pertencente ao litoral da Baía de Guanabara - e não ainda a praia oceânica que fará a glória turística da cidade a partir da década de 50 .

\section{Século XIX: tudo muda}

Um extraordinário salto de qualidade se opera no século XIX, em relação à imagem da praia no Brasil. O fato é que os próximos registros sobre seu uso estão relacionados à saúde e ao tratamento terapêutico.

Nessa ascensão do modelo terapêutico de praia, a aristocracia tem papel fundamental. É ela quem, na Europa, legitima os locais onde o banho curador se dará. Apenas para citar alguns exemplos, é no mar de Weymouth que o rei Jorge III se banhará freqüentemente, utilizando-se do prédio construído a partir de 1780 por seu irmão, o duque de Gloucester. Logo depois, em 1794, a Alemanha começa a edificar sua primeira grande estação balneária, em Doberan, nas terras do grão-duque de Mecklemburg-Schwerin.

O panorama geral europeu, enfim, na virada do século XVIII para o XIX possivelmente influencia a decisão de D. João VI, que chega ao Brasil em 1808, vindo justamente da Europa, de tratar a doença de pele que o atinge com banhos de água salgada, instalando para isso uma construção na Praia do Caju, em 1817. Isso favorece a hipótese de uma passagem gradativa da praia como depósito de excrementos e locus de trabalho a balneário médico a partir da chegada da família real ao Brasil.

Outras pistas ajudam a tornar menos incompleta essa transformação do uso da praia ao longo do século XIX. A primeira delas é dada pela presença do cenário do litoral em alguns romances brasileiros escritos no período, o que invoca a idéia de que a praia se tornara ao menos familiar para outros segmentos sociais que não os escravos. Em A moreninha (1845), por exemplo, encontraremos como pano de fundo do primeiro encontro dos protagonistas Carolina e Augusto, en- 
tão crianças, "uma das belas praias do Rio de Janeiro" (cf. Macedo, s/ d, 70-71). Note-se ainda que poetas como Álvares de Azevedo (18301852) fazem da praia palco para suas elocubrações ${ }^{4}$. Tais furtivas idas literárias à praia permitem uma outra suposição, também insinuada por Corbin em relação à Europa: a de que a Escola Romântica, com seu apelo à paisagem e à natureza nacional, tenha contribuído para a nova configuração simbólica da beira-mar ${ }^{5}$.

Já na virada do século XIX para o XX, a expansão da malha urbana do Rio, através do aperfeiçoamento de sua rede de transportes, também reconfirma a nova situação da praia como algo saudável, não mais como perigo ou sujeira. Com sentidos e funções diferentes, vão entrando em cena bondes e trens; os primeiros, garantindo a expansão da cidade para a Zona Sul litorânea, e os segundos deslocando a população de trabalhadores de suas moradias no centro da cidade para os subúrbios ${ }^{6}$. Começa aí a construção, tanto simbólica quanto espacial, daquele que seria eleito o lugar edênico da cidade: a Zona Sul.

Nesse sentido, é de fundamental importância a total remodelação urbana promovida no início do século XX pelo Prefeito Francisco Pereira Passos na cidade do Rio, capital federal, com o estímulo e sob o patrocínio do então presidente Rodrigues Alves. Para se ter a dimensão de tais novidades na vida prática das pessoas, é preciso saber um pouco mais sobre a área principalmente atingida pela reforma de Pereira Passos. Num esforço de síntese, os objetivos primeiros das obras seriam a reforma do porto; a construção das avenidas Rodrigues Alves e Central (atual Avenida Rio Branco); a melhoria de acesso à Zona Sul da cidade, através da criação da Avenida Beira-Mar; melhoramento do acesso à Zona Norte por via da abertura da Avenida Mem de Sá e do alargamento das ruas Frei Caneca e Estácio de Sá; a pavimentação da cidade e, de modo mais geral, a ampliação da infra-estrutura urbana. Para a conquista destes objetivos, o poder público utilizou-se do método da demolição de áreas densamente povoadas, localizadas na região central do Rio, expulsando mais de 14 mil pessoas de suas residências - cortiços e outras formas de habitação popular.

\section{A Zona Sul nas primeira décadas do século $\mathrm{XX}$}

Nesse quadro, um novo deslocamento passa a ocorrer: o centro do Rio, pensado a princípio pelos mentores da nova ordem como o espaço valorizado por excelência, vai sendo identificado com o passado colonial e perdendo gradativamente seu valor em favor de uma área a rigor nova. Esta área, a Zona Sul da cidade, se torna a representação 
da modernidade. Dentro dela, um lugar especial cabe à praia. No entanto, agora a praia não é mais aquela ligada ao terreno primeiro da colonização, ou seja, à orla da Baía de Guanabara. Esta é deixada para trás, depois de mudado seu traçado e seu perfil, por sucessivos aterros (resultantes de desmanches de morros) que diminuiram seu espelho d'água de 700 metros para apenas 381 - um tipo de ação sobre a paisagem natural que se repetirá anos mais tarde, quando da construção do perfil moderno da praia de Copacabana, por exemplo. Nesse momento - inicio do século XX - quando se fala em praia, subentende-se a praia oceânica, que cada vez mais será iconizada por Copacabana, então um terreno virgem associado à saúde, ao moderno e ao belo ${ }^{7}$.

Gideon Bosker e Lena Lencek (1998), em estudo histórico sobre a praia, também frisam as primeiras décadas do século XX como o início do triunfo de uma nova concepção acerca deste espaço. Fazendo uma ponte entre o uso do litoral pela Europa e o trauma causado pela Primeira Guerra Mundial, os autores afirmam que o conflito levou a uma idéia de corpo baseada na reação à trágica visão dos milhares de corpos destroçados nas batalhas - a "dessacralização do corpo humano" - e que funcionou como uma reação vitalista, de despojamento e de culto às formas corporais. Esta nova noção de corpo acarretaria tanto uma mudança no guarda-roupa - o corpo agora deveria ser mostrado, exibido, proclamado - quanto a busca do contato com a natureza. Dai a "heliofilia", a busca da praia e da cor bronzeada como signo desta vida tão desejada.

Bosker e Lencek lembram que é justamente uma estilista, Coco Chanel, quem lança, nos anos 20, o bronzeado como "moda", aparecendo "com a cor de um marinheiro" nos mais altos círculos europeus. Isto coloca uma outra questão, pouco explorada pelos autores, mas que para nosso estudo é preciso desenvolver mais, ou seja, a referência à classe social embutida neste processo. Se antes deste período a cor morena é associada a pessoas que se expõem ao sol por força de seu trabalho, ou seja, que têm de trabalhar para viver, e portanto a individuos das classes mais baixas, no início do século inverte-se a equação. Se este culto ao corpo no momento imediatamente posterior à guerra perpassa todos os que estiveram envolvidos no conflito, numa segunda fase ele é institucionalizado como um bem pertencente à esfera da classe social mais abastada. Semelhante ao que ocorreu quando da transformação da praia em espaço terapêutico, em que reis e nobres ditavam as regras, as modas e os bons locais no litoral, na 
Europa agora plebéia artistas, intelectuais e modistas famosos mundialmente se tornam os formadores de opinião por excelência. Neste sentido, este "culto ao moreno" acabará tornando esta cor um sinal de distinção, um exercício que marca corporalmente aqueles que têm tempo e dinheiro disponíveis para se bronzearem.

No Brasil, e mais especificamente no Rio de Janeiro, o culto ao corado, como se viu, também se inicia na virada do século, mas muito mais ligado à preocupação com a insalubridade e a doença. Copacabana se torna o local da saúde, símbolo da nova nação que se desenvolvia a lépidos passos, sem os entraves que áreas mais antigas da cidade, com população e problemas já tradicionais, ofereciam aos novos ideais de beleza e modernidade acionados pelo Estado e segmentos dominantes. Tais segmentos afluem então a Copacabana e se dedicam a construir suas mansões a partir dos mais variados estilos.

A preocupação com o bairro se traduz numa série de obras, já insinuadas no final do século anterior, mas que se aceleram até culminarem com o redesenho da orla, já nos anos 70 do século XX. Em 1892, por exemplo, inaugura-se o Túnel Velho, oficialmente chamado de Alaôr Prata, que liga a área mais antiga de Botafogo, próxima ao cemitério São João Batista, à rua Siqueira Campos, em Copacabana. Em 1906, no final do governo de Pereira Passos, o Túnel Novo amplia o raio de ocupação possível do bairro, ligando Botafogo ao Leme e completando o movimento sugerido pela criação da Avenida BeiraMar, ou seja, de saída do centro da cidade em direção a Copacabana. O mesmo prefeito é responsável pelo início das obras da Avenida Atlântica, que margeia a praia copacabanense. Ícone máximo da Copacabana residencial e aristocrática das primeiras décadas do século XX, o Hotel Copacabana Palace abre suas portas em 1923 para abrigar a elite européia visitante.

Mas será após a Segunda Guerra que a representação de Copacabana ganhará novos contornos. A partir daí, a vertente francesa que presidira a urbanização a la Pereira Passos do início do século na cidade do Rio será substituída pela direta influência de outro modelo: o americano.

Produtos norte-americanos invadem o mercado nacional e seus comerciantes encontram em Copacabana o cenário ideal de vendas. $O$ bairro assiste à inauguração do primeiro supermercado da cidade, do primeiro Bob's, inaugurando a era do fast-food, além de uma variedade impressionante de itens de consumo que vão desde absorventes descartáveis (em substituição às toalhinhas higiênicas), passando por 
enlatados, óculos Ray-ban, eletrodomésticos, canetas esferográficas, cereais em pacote e cortinas venezianas de alumínio. A década de 40 se delineia, assim. como o

"momento crucial de inflexão do imaginário simbólico deste território. Momento em que, abandonando as imagens de paraiso bucólico e higiênico do início do século ou de balneário aristocrático das primeiras décadas, [Copacabana] parte em direção à vertente cosmopolita e consumista que the confere a feição de bairro moderno da cidade; não mais um paraiso somente criado pela natureza aprazivel, mas principalmente pelo que oferece em termos novidadosos de consumo e lazer:" (Pereira, 1991:11)

\section{O espaço demarcado: a dicotomia Zona Norte/Zona Sul}

Resta enfatizar, na análise de Pereira sobre Copacabana neste momento, alguns aspectos mais diretamente interessantes para o presente estudo. Um deles é que o modelo americano de modernização via consumo denota uma mudança de padrão do aristocrático para o individualizante/ democratizante. O consumo de massas, no caso do Estados Unidos, se liga a toda uma simbologia da democracia do acesso ao consumo e da igualdade de oportunidades num mercado encarado como livre "por natureza".

A visualização das diferenças na praia trará a marca dessa simbologia. Reportagens da época ajudam a construir e divulgar esse discurso ${ }^{3}$ :

"(...) Em Copacabana vale tudo e quase não existem comadres para falar da vida alheia. Uma garota da Tijuca, se fizesse a metade das travessuras que faz um brotinho do Posto 5 , seria banida do lar: Mas o mar, o grande nivelador, garante a mão. As mulheres podem andar de 'slack' e fumar na rua sem que ninguém se volte para olhar. Os homens empurram carrinhos de criança com britânica naturalidade. E o amor é livre, no bom sentido. Jovens casais têm o direito de passear agarradinhos, sem que ninguém ache feio." (O Cruzeiro, apud Pereira, 1991:58)

Para além da definição subliminar dos papéis de gênero, através da insinuação dos usos e gostos proibidos a homens e mulheres no Rio da época (início dos anos 50), mas que são "liberados" na praia, insinua-se aí também a diferença entre a "garota da Tijuca" e o "brotinho do Posto 5". Volta à cena, mais nitidamente delineado, o perfil do personagem subur- 
bano, como o morador de um espaço onde a liberdade individual e a moral estão mais rigidamente limitados ${ }^{9}$. Num movimento duplo, define-se também o morador da Zona Sul, através da oposição tradicional - associado ao subúrbio e seus habitantes - e moderno, identificado com quem mora perto da praia.

\section{As turmas de jovens}

Definindo, enfim, as regiões da cidade e os bairros dentro dela, o esforço na década de 50 e início dos 60 se casa ao de alocar simbolicamente estes espaços. Neste sentido, é interessante notar que um novo agente social - a juventude -, que desponta também neste momento, trata logo de se vincular ao espaço construído como novo, ou seja, à praia ${ }^{10}$. As "turmas de jovens" , também chamadas de "turmas de praia", são constituídas de bandos de jovens basicamente das camadas média e alta que passam a utilizar a praia como sinal de diferenciação em relação ao comportamento adulto.

A representação máxima do movimento de turmas de jovens é a chamada "turma dos cafajestes". Rapazes filhos das classe abastadas se reuniam em Copacabana para ir a festas e conquistar garotas que, por sua vez, pareciam enxergar o grupo como uma "porta" para além dos limites domésticos. O relato autobiográfico do integrante mais famoso da turma, Carlos Imperial, é bastante esclarecedor tanto sobre a condição de transgressão da turma diante de um comportamento convencional quanto do papel da praia neste esquema. Vejamos aqui um trecho do livro, onde o autor é apresentado ao grupo:

"No fim da festa, Betinho convidou-me para fazer parte de um grupo que iria 'tirar uma onda' na Barra da Tijuca. Pedi explicaçôes sobre a 'onda'. Betinho sorriu:

- Você está vendo esses brotos lindos que estão comigo? Gostou de alguma delas? Iremos em grupo - garotas e rapazes - fazer um programa.

(...) Ele insistiu:

- Tenho Quilha na mala do meu carro. (...) Você está por fora da 'onda da Quilha'? (...) Todas estas bonecas que estão comigo são doidas por Kelene. Nós tratamos de Quilha, para despistar. (...) Quando atingimos a Avenida Niemeyer, Raul distribuiu lançaperfume às garotas, que cheiravam e sorriam, maravilhadas." (Imperial, 1973:20-21). 
Ipanema era uma extensão menos freqüentada de Copacabana até os anos 40. Não que antecedentes ilustres não tenham desde o início do século XX se encantado com suas belezas naturais - haja vista a crônica de 1917 feita por João do Rio em homenagem à praia, que chama de "maravilhosa" (in Peixoto, Barata, Gaspar e Abreu, 1994:29-31); no entanto, estas eram preocupações esporádicas até a metade do século, como relata Tom Jobim, lembrando de sua infầncia e adolescência, ao Jornal de Ipanema, já na década de 70: "Enquanto Copacabana era lugar de casas luxuosas, Ipanema era um lugar de casinhas pequenas. Quem não podia comprar casa em Copa, vinha pra cá, porque era mais barato e mais longe. Principalmente mais longe." (in Peixoto, Barata, Gaspar e Abreu, 1994:41)

A praia portanto começa a se bifurcar a partir deste momento - a metade do século - em duas pontas, Ipanema e Copacabana, passando gradativamente a primeira a crescer em importância diante da segunda. $\mathrm{E}$ o compositor citado acima, ele mesmo morador de Ipanema desde um ano de idade, tem tudo a ver com a consolidação final desta mudança, como veremos logo a seguir. É que neste momento, um outro discurso, além do teórico e do jornalístico, também colabora para esta conformação nova. É o discurso musical, através particularmente de um movimento que surge então com toda a força, ou seja, a bossa nova, cujas canções serão analisadas mais detidamente aqui.

\section{Corpo dourado e morenidade}

Não pretendendo esgotar esta questão, porém apenas sinalizá-la, indico aqui três canções que funcionaram como tijolos na construção mítica da Zona Sul, e que apontam também o movimento em direção a um novo icone de praia, ou seja, Ipanema: a mais antiga, Copacabana, de João de Barro (Braguinha) e Alberto Ribeiro, lançada em 1947 pela voz de Dick Farney; Teresa da praia, de 1954, tendo como autores Tom Jobim e Billy Blanco e cantores Dick Farney e Lúcio Alves; e afinal a decantada Garota de Ipanema (1962), de Tom e Vinícius de Moraes, pela voz de João Gilberto'2. Vamos às letras das canções:

\section{Copacabana}

Existem praias tão lindas, tão cheias de luz

Nenhuma tem os encantos que tu possuis

Tuas areias, teu céu tão lindo

Tua sereia, sempre sorvindo 
Copacabana, princesinha do mar

Pelas manhãs tu és a vida a cantar

E à tardinha o sol poente

Deixa sempre uma saudade na gente

Copacabana, o mar eterno cantor

Ao te beijar ficou perdido de amor

E hoje vive a murmurar

Só a ti Copacabana eu hei de amar

\section{Teresa da praia}

- Ô Lúcio/- Eu?/ - Arranjei novo amor no Leblon/- Não diga/ Que corpo bonito, que pele morena, que amor de pequena, amar é tão bom/ - Tão bom! Ö Dick/ - Sim?/ - Ela tem um nariz levantado, os olhos verdinhos, bastante puxados, cabelo castanho.../ - E uma pinta do lado... - É a minha Teresa da praia/- Se ela é tua, é minha também/ - O verão passou todo comigo/ - O inverno pergunta com quem... - Então vamos a Teresa na praia deixar, aos beijos do sol e abraços do mar. Teresa é da praia/ -Não é de ninguém/ - Não pode ser tual - Nem tua também.

\section{Garota de Ipanema}

Olha que coisa mais linda, mais cheia de graça

É ela a menina que vem e que passa

Num doce balanço a caminho do mar

Moça do corpo dourado do sol de Ipanema

O seu balançado é mais que um poema

É a coisa mais linda que eu já vi passar

Ah, por que estou tão sozinho?

Ah, por que tudo é tão triste?

Ah, a beleza que existe

A beleza que não é só minha

Que também passa sozinha

Ah, se ela soubesse que quando ela passa

$O$ mundo inteirinho se enche de graça

E fica mais lindo por causa do amor

De modo rápido, sugiro apenas, em primeiro lugar, o mapeamento por estas canções dos bairros da orla carioca que passam a iconizar toda a região Zona Sul da cidade: Copacabana, Leblon e Ipanema. Em segundo lugar, é preciso apontar para o fato de que este investimento simbólico na 
região citada toma a forma da mulher - Copacabana, feminizada, é a "princesinha do mar", enquanto as outras duas letras falam de modo mais dircto de duas mulheres míticas desse local igualmente mítico que é a praia.

Devemos ainda observar aqui que quem canta é um sujeito masculino, nos três casos; a entoação das cantigas se distingue no sentido de que, se a primeira lembra as canções americanas a la Frank Sinatra, a segunda já insinua uma batida diferente, mais próxima do que a terceira encarna, ou seja, o modo de cantar da bossa nova, menos grandiloqüente e mais coloquial. Em segundo lugar, o individuo construido pelo primeiro texto aponta para um homem que contempla a praia e a canta, à maneira romântica; enquanto isso, os outros dois textos apontam para homens que cantam mulheres num local especifico - a praia. Uma segunda diferença é que, se a primeira persona canta uma praia que contempla, buscando defini-la, as outras duas personas optam por colocar os espaços a que se referem como pano de fundo, como se estes fossem já conhecidos, e portanto eles se sentissem à vontade para percorrê-los musicalmente.

O universo registrado pela poética dos versos, passando agora para o terceiro nível de análise, confirma isso, centrando o foco do texto no espaço do lazer corporificado pela Zona Sul delimitada em Copacabana, Ipanema e Leblon. Embora esta conclusão tenha várias implicações, o que importa no momento é indicar, primeiro, a eleição de um espaço privilegiado como aquele que gostosamente se desliga do trabalho, encarando o contrário deste como o locus do prazer. Este prazer toma a forma feminina, da relação com o sexo oposto, e também de contato com a natureza - tudo isto considerado conjugado na praia da Zona Sul. A palavra beleza parece sintetizar este universo. E que beleza é esta? Que corpo de mulher é cantado? Trata-se da mulher branca queimada de sol. de comportamento sexual livre, em movimento e em intima relação com o entorno, o espaço natural do mar, da areia, do sol.

O corpo dourado, agora literalmente cantado em prosa e verso, se torna a encarnação dessa Zona Sul livre, moderna, consumista e chique. O corado transforma-se em ouro, numa referência nem tão casual a um certo status sócio-economico, onde a cor morena funciona como marca de distinção em relação aos não-habitantes do paraíso Zona Sul, aos não-morenos ${ }^{13}$. Neste sentido, as observações de Bosker e Lencek sobre o bronzeado como moda de gente famosa se tornam totalmente pertinentes no Brasil dos anos 60 . 
Tem-se, enfim, que a praia é iconizada a partir dos anos 50 como espaço de sociabilidade relacionado a categorias como liberdade, modernidade e acesso a oportunidades e a bens de consumo. Por outro lado, é também neste momento, nos anos 50 , que um determinado discurso sobre o Rio de Janeiro emerge, conformando-o tanto espacialmente, com divisões nítidas entre a Zona Sul, a Norte e os subúrbios, como corporalmente, através da ascensão do ideal de morenidade, adquirido por via da fruição da praia.

\section{Anos 60: Ipanema reina}

A expansão de Ipanema ocorre gradativamente. Um dos ícones da faceta transgressora já indicada pelas turmas de jovens aponta para a emergência de um outro agente social - a "mulher moderna". Esse agente tem agora uma nova conformação, estruturando-se a partir de uma ação política reivindicatória direcionada à sua especificidade - o feminismo ${ }^{14}$.

O novo na praia agora tem também novo rosto - e este é o de Leila

136 Diniz. Atriz de TV e de teatro, Leila passa a encarnar o que se chamou à época de "espírito carioca". Esse tal espírito se apropria de um adjetivo - "solar" - que remete imediatamente ao espaço da praia, que ela efetivamente freqüentava. Assim, quando, em 1972, Leila Diniz mostra sua barriga de grávida, fruto de uma relação consensual, e não legal e/ou religiosamente constituída, num biquini em plena areia de Ipanema, ela não só consolida sua imagem de "mulher moderna", livre (cf. Goldenberg, 1994), mas também estabelece a praia como o palco por excelência dessa exposição de modernidade feminina.

Anos mais tarde, no final da década de 70 , Ipanema novamente serve de palco para a demonstração de outro tipo de "vanguarda comportamental". Fernando Gabeira, ex-guerrilheiro urbano, opositor do governo militar por este exilado na Europa, volta em função da anistia política decretada no país em 1979, e no verão seguinte aparece de tanga lilás de crochê em Ipanema - quando a moda masculina de praia ditava calção ou sunga de banho - detonando uma discussão via mídia sobre modelos de masculinidade e preferências sexuais (cf. Chacal, 1998). Antes disso, porém, o próprio movimento hippie em versão brasileira elegeria a praia como um de seus palcos, através da escolha de um pedaço de Ipanema - as famosas "dunas do barato", no pier - onde se construía um emissário submarino para lançamento de esgoto ao mar por parte dos grupos ligados a esta "onda" (idem). 
Enquanto lpanema se construía como locus da vanguarda - entendida como lançamento de novidades, particularmente na área comportamental, artística e de vestuário - , Copacabana ia sendo cada vez mais procurada pela população carioca em geral, que a encarava como um signo de mobilidade ascendente ${ }^{15}$. O inchaço imobiliário resultante do investimento simbólico naquele espaço da cidade foi analisado com agudeza por Velho (1989) que, em seu estudo sobre os moradores recém-chegados a Copacabana, constata que

"Ficou (...) claro que [os entrevistados] representavam Copacabana como o locus das boas coisas da vida. Isso patenteava-se ao contrastarem a vida copacabanense com a da Zona Norle, do subúrbio, da periferia ou mesmo de outras cidades. Enfatizavam o comércio, os divertimentos, a segurança, os 'recursos', bens ou qualidades ausentes ou mais raros' em outros locais. Sem eliminar a atuação da propaganda, da especulação imobiliária, da 'imitação' de estratos mais altos(....) verifica-se a existência de uma estratégia de mobilidade social baseada em estabelecimento de objetivos claros e de um esforço às vezes gigantesco." (Velho, 1989:7-8)

Pode-se descrever os anos 70, a partir desse relato, como a culminância do processo apontado por Pereira, em que valores como mobilidade social, liberalidade democratizante e acesso a bens de consumo forjaram o ícone Copacabana. É a partir dessa imagem que pessoas provenientes de outras regiões da cidade e do país afluem ao local, auxiliadas pela especulação imobiliária que constrói a partir dos anos $50 / 60$ os agora famosos prédios de conjugados, quitinetes, sala-equarto.

\section{Anos 80}

O Rio de Janeiro chega aos anos 80 com pouco mais de cinco miIhões de habitantes ${ }^{16}$. Talvez como reflexo deste grande número de pessoas, e em certo grau também como parte do movimento de segmentação espacial da cidade, as praias da Zona Sul carioca passam por uma mudança de nomenclatura, que a partir de então se refere não mais ao bairro como um todo, mas a pontos determinados dentro do mesmo bairro - o Posto Nove, o Arpoador, a Farme de Amoedo, e não mais a praia de Ipanema, por exemplo. 
Esta nova dinâmica tem a ver também com a rearrumação sofrida pela beira-mar como um todo, a partir do projeto Rio Orla, realizado na virada da década pela prefeitura, e que reformou os postos de salvamento, além da padronização dos quiosques para venda de comestíveis na calçada e a instalação de iluminação noturna do Leme ao Leblon.

Uma outra mudança, mais importante ainda, diz respeito à reestruturação do transporte do Rio de Janeiro nestes anos. Em primeiro lugar, em 1984, inaugurou-se uma série de linhas de ônibus que visavam integrar a Zona Sul ao subúrbios, utilizando para isso a passagem pelo Túnel Rebouças, até então vedado a coletivos. Eram ônibus que tinham seu ponto final em locais estratégicos (como São Cristóvão, Maracanã e Méier) do itinerário de quem vinha de subúrbios distantes e ia a Ipanema, Copacabana e Leblon. Isso não ocorreu sem protestos de moradores que reclamavam contra a "invasão" de suburbanos que haveria então. Exemplos disso são os trechos abaixo, retirados do Jornal do Brasil à época, em que moradores e trabalhadores de Ipanema expressam seu descontentamento quanto às famigeradas linhas de integração:

"É chocante dizer, mas eles não estão acostumados com os costumes do bairro. Nem vou mais à praia aqui. É farofeiro pra tudo quanto é lado, olhando a gente de um modo estranho. Ficam passando aquele bronzeador. A sensação é de que estão invadindo nosso espaço. (Maria Luiza Nunes dos Santos, ex-frequientadora da praia da Garcia D'Ávila e que agora só vai ao Pepino).

- Fica essa negrinhagem ai na porta... (Cristina Campos, vendedora da [butique] Spy and Great)" (apud Melo, 1994:251-251)

Uma música de um grupo de rock, lançada no mesmo momento e provavelmente sob o impacto deste evento, sugere o desdobramento destas discussões. Nós vamos invadir sua praia (1985), do paulista Ultraje a Rigor, define a orla basicamente como um território rigidamente demarcado, onde a chegada de estranhos é sentida como invasão.

Nós vamos invadir sua praia

Daqui do morro dá pra ver tão legal/O que acontece aí no seu litoral 
Nós gostamos de tudo, nós queremos é mais Do alto da cidade aré a beira do cais

Mais do que um bom bronzeado/Nós queremos estar do seu lado

Nós tamo entrando sem óleo nem creme/Precisando a gente se espreme

Trazendo a farofa e a galinha/Levando lambém a vitrolinha Separa um lugar nessa areia/Nós vamos chacoalhar a sua aldeia

Mistura sua laial ou foge da raial sai da tocaial pula na baia Agoral nós vamos invadir sua praia

Agora, se você vai se incomodar/Enıão é melhor se mudar Não adianta nem nos desprezur/Se a gente acostumar a gente vai ficar

A gente tá querendo variar e a sua praia vem bem a calhar Não precisa ficar nervoso/Pode ser que você ache gostoso Ficar em companhia tão saudável/Pode até te ser bastante recomendável

A gente pode te cutucar, não tenha medo/Não vai machucar Mistura sua laialou foge da raia/sai da tocaia/pula na baial Agoral nós vamos invadir sua praia.

A música parece uma junção de vários espectros que atemorizam as classes abastadas e médias no Rio. Feita e cantada por paulistanos, remete à imagem da cidade de São Paulo como província sem praia; sob o signo do morro, invoca a figura do favelado; manejando símbolos como "farofa", "galinha", "vitrolinha", traz à baila o personagem do "farofeiro" de praia, ligado ao do suburbano no sentido de alguém pouco habituado aos usos e costumes da praia, por não ser dela freqüentador assiduo. Além disso, este personagem, por morar longe e não ter muito dinheiro, supostamente não pode se dar ao luxo de deixar para almoçar em casa ou gastar em lanches pelas ruas.

Todo esse adensamento de símbolos ajuda a delinear as fronteiras entre os habitués e os marginais da praia, entre os "donos do pedaço" e os outros. Lida por este recorte, a música pode representar o resultado do processo delineado páginas atrás, de especialização espacial da cidade, vinculada a uma definição de territórios a partir de critérios explícitos de classe social e também de cor, como vimos pelos comentários da vendedora de Ipanema, acima citados. 


\section{Anos 90}

Os últimos anos do século XX são um momento em que a praia carioca se torna novamente assombrada pelo fantasma de uma outra "invasão". Desta vez, ela ganha o nome de "arrastão", e assinala a visibilidade de um novo grupo social na cidade: as galeras jovens dos bailes funk. Em sua maioria negros e pobres, muitos deles moradores de subúrbios, estes jovens irrompem no cenário da praia num tórrido domingo de outubro de 1992, voltando desde então, ao menos como ameaça, a assustar os dias de verão dos moradores da cidade, particularmente dos brancos mais abastados.

Ao mesmo tempo, uma curiosa inflexão ocorre em relação à imagem de saúde associada à praia. $\mathrm{O}$ discurso ecológico, acompanhado do médico, irá ressignificar a praia como o local do sol perigoso à pele, e portanto à saúde, e como um foco "poluído". É possível assim que os anos 90 assinalem uma fase de transição para outra conformação simbólica deste espaço urbano, bem menos idílica que a anterior. Ao mesmo tempo, pode-se também pensar que isso corresponda a uma nova ordenação em relação aos valores que cercam os espaços públicos e privados da cidade, com a negativação dos primeiros diante dos últimos. Ironicamente, no caso da praia, parece que estamos assistindo a uma tentativa de reedição em nova roupagem da sua primeira representação simbólica, do tempo colonial. Será, então, que se voltará a pensar a orla marítima como um espaço de sujeira e de deterioração do corpo?

\section{Mas afinal que história é essa?}

O material acima exposto poderia ser facilmente encarado como uma pesquisa que se quer antropológica, e que se serve de uma história événementiel. Afinal, alinhavou-se uma série de acontecimentos que, embora sem uma perspectiva claramente evolucionista, aponta para uma progressão, uma experiência cumulativa que desaguará em determinado modo de ver a cidade, a praia, a cor, o corpo.

Pedirei a ajuda de Schwarcz (1995) para tentar escapar desta armadilha. Em seu texto, a autora recorre à conceituação de Marshal Sahlins (1994) para dar conta da equação história-antropologia de uma forma não-opositiva, e sim complementar (ou o mais próximo disso que se possa chegar). Segundo este, haveria uma forma de encarar a história, de acordo com a qual esta se apresentaria como o entendimento do fenômeno acontecido, como a atenção às novas ocorrências; por sua vez, a forma de apreensão destes acontecimentos se daria a 
partir de uma estrutura mental pré-determinada, que poderia ser buscada com o auxílio da antropologia. Cunha ele então a expressão estrutura da conjuntura para abarcar justamente este complexo procedimento - ao mesmo tempo a sinalização de uma novidade na vida social por parte de um grupo e sua codificação de acordo com o modo de pensar próprio deste grupo.

Analisando o presente texto à luz das sugestões citadas acima, o que se pretendeu foi indicar uma série de acontecimentos, como intuito não de narrar um épico, mas de tentar vislumbrar entre eles alguma recorrência, a reincidência de um modo de pensar que orientou as ações. Nesse sentido, se poderia pensar nestas histórias como uma espécie de equacionamento constante de um feixe de pensamentos, em que a cor, o corpo e o espaço urbano praia sinalizam uma discussão a respeito do lugar dos diferentes grupos sociais que habitam a cidade do Rio de Janeiro. Deste modo, o fascínio maior do estudo da praia advém exatamente de que ela pode ser pensada como espaço de negociação ininterrupta de identidades espaciais, de classe e raciais.

Num segundo viés, o estudo contempla ainda o percurso da idéia de natureza entre nós, tal como expressa nos termos corpo, cor/raça e praia; e da idéia de cultura, inserida nos processos de apropriação de territórios por parte de grupos.

Referências bibliográficas

AMADO, Jorge. Capitães da areia. Rio de Janeiro: Record, 1977, Iª ed. 1937.

ANUÁRIO Estatístico da Cidade do Rio de Janeiro. Rio de Janeiro: Iplanrio, 1990.

ASSIS, Machado de. Dom Casmurro. São Paulo: Abril, 1971.

BOSl, Alfredo. História concisa da literatura brasileira. Rio de Janeiro: Paze Terra, 1975.

BOSKER, Gideon; LENCEK, Lena. The beach: the history of paradise on Earth. New York: Viking Press, 1998.

CARVALHO, José Jorge de. The multiplicity of black identities in Brazilian popular music. Brasilia: Depto. Antropologia, UnB, 1994, série Antropologia, n. 163.

. "Black music of all colors: the construction of black ethnicity in ritual and popular genres of Afro-Brazilian music". In: Béhage, Gérard (org.), Music and black ethnicity. The Caribbean and South America. Miami: North-South Center, 1994, p. 187-206. 
CHACAL. Posto 9. Rio de Janeiro: Relume Dumará/Rioarte, 1998.

FARIAS, Patrícia. Sobre rock, jornais e Brasil. Rio de Janeiro: CIEC-ECO/UFRJ, série Papéis Avulsos n. 46, 1994.

. "Festa, nação, etnia, personalidade: notícias da Abolição". In: Contins, Márcia; Maggie, Yvonne (eds.), Visões da Abolição, 1988. Rio de Janeiro: CIEC/UFRJ/Fundação Museu da Imagem e do Som, 1997.

FREYRE, Gilberto. Sobrados e mocambos. Rio de Janeiro: José Olympio/MEC, 1977, $5^{\text {a }}$ ed.

FRITH, Simon. Sound effects: youth, leisure, and the politics of rock'n'roll. New York: Pantheon Books, 1981.

GOLDENBERG, Mírian. "Leila Diniz: a trajetória de uma mulher revolucionária". In: Temas e Textos, IFCS/UFRJ, 1995, n. 1, p . 29-39.

HOBSBAWM, Eric. História social do jazz. Rio de Janeiro: Paz e Terra, 1990.

CORBIN, Alain. $O$ território do vazio. A praia e o imaginário ocidental. São Paulo: Cia. Das Letras, 1989.

LAFONT, Hubert. "As turmas de jovens". In: Sexualidades ocidentais. São Paulo: Brasiliense, 1983.

IMPERIAL, Carlos. Memórias de um cafajeste. Rio de Janeiro: Companhia Editora Americana, 1973, $4^{\mathrm{a}}$ edição.

MACHADO PAES, José. Culturas juvenis. Lisboa: Imprensa nacional Casa da Moeda, 1993.

MELO, João Batista de. As memórias de um João-Ninguém - o farofeiro de Ipanema. Valença: Valença, 1994.

MOURA, Roberto. Tia Ciata e a Pequena África no Rio de Janeiro. Rio de Janeiro: Prefeitura do Rio de Janeiro, Secretaria Municipal de Cultura, Departamento Geral de Documentação e Informação Cultural, Divisão de Editoração, 1995, 2ª ed.

MACEDO, Joaquim Manoel de. A moreninha. Rio de Janeiro: Ediouro, s.d.

PEIXOTO, Mário; BARATA, Carlos Eduardo; GASPAR, Cláudia Braga; ABREU, Marilúcia. Villa Ipanema. Rio de Janeiro: Novo Quadro, 1994. 
PEREIRA, Simone Andrade. Os anos dourados. Copacabana e o imaginário urbano dos anos 50. Rio de Janeiro: Dissertação de mestrado para o Programa de Pós-Graduação em Teoria da Comunicação e da Cultura, Escola de Comunicação/UFRJ, 1991, mimeo.

PEREIRA DA SILVA, Maria Laís. Os transportes coletivos na cidade do Rio de Janeiro - tensões e conflitos. Rio de Janeiro: Secretaria Municipal de Cultura, Turismo e Transportes, Departamento Geral de Documentação e Informação Cultural, Divisão de Editoração, 1992.

SAHLINS, Marshall. Ilhas de História. Rio de Janeiro: Zahar, 1994.

SAN MARTINI, Lindita (coord. edit.). Copacabana - 1892/1992. Subsídios para a sua história. Rio de Janeiro: Riotur, 1992.

SCHWARCZ, Lilia Moritz. Retrato em branco e negro: jornais, escravos e cidadãos em São Paulo no século XIX. São Paulo: Cia. das Letras, 1987.

. "Complexo de Zé Carioca - Notas sobre uma identidade mestiça e malandra". In: Revista Brasileira de Ciências Sociais, 29, ano 10 , outubro de 1995 , pp.49-63.

VELHO, Gilberto. A utopia urbana - um estudo de antropologia social. Rio de Janeiro: Zahar, 1989, $5^{\text {a }}$ ed.. I" ed. 1973.

\section{Notas}

I Este texto é uma curta versão de um capítulo de minha tese de doutorado para o Programa de Pós-Graduação em Sociologia e Antropologia do Instituto de Filosofia e Ciências Sociais - IFCS/ UFRJ, em andamento.

2 Segundo dados do IBGE, o município do Rio de Janeiro possuía 5.551.538 habitantes em 1996.

3 Este processo se dará também em outras cidades litorâneas e portuárias, como Salvador, por exemplo, e fará com que já no final do século XIX, em 1870, um cronista estrangeiro afirme (a respeito da cidade baiana): "Se não se soubesse que ela [a cidade de Salvador] fica no Brasil, poder-se-ia sem muita imaginação tomá-la por capital africana (...), na qual passa inteiramente despercebida uma população de forasteiros brancos puros. Tudo parece negro: negros na praia, negros na cidade, negros na parte baixa, negros nos bair- 
ros altos. Tudo o que corre, grita, trabalha, tudo o que transporta e carrega é negro." (Robert Avé-Lallemant, apud Moura, 1995, p . 28)

4 Diz ele em "Sonhando":

A praia é tão longa! e a onda bravia
as roupas de gaza te molha de escuma;
De noite - aos serenos - a areia é tão fria,
Tão úmido o vento que os ares perfuma!
(Azevedo, apud Bosi, 1975:121).

5 Já em 1900, em seu livro Dom Casmurro, Machado de Assis menciona como passeios habituais dos personagens Bentinho, Capitu, Escobar e Sancha a ida à praia da Glória, em frente à casa dos dois primeiros (Machado de Assis, 1971:309).

6 Note-se que todo esse processo de "desapropriação via transportes" não se deu sem tensões entre "renovadores" e setores da sociedade assim marginalizados. Sobre a implantação da rede de transportes de massa no Rio de Janeiro e sua repercussão popular, cf. 144 Pereira da Silva, 1992.

7 Muito significativa, neste sentido, a estrofe em versos estampada nos bondes que fazem o caminho até Copacabana. Diz ele: "Sofrei de béri-béri! Ouvi atentos/este conselho que vos não engana/usai banho de mar, tereis provento,/mas, em Copacabana." (apud Pereira, 1991,33)

8 Tenho lidado com material jornalístico em alguns estudos (cf. Farias, 1994 a, 1997) a partir da idéia de que este pode ser tomado como uma chave importante de compreensão tanto do pensamento dominante de uma época como do modo de construção deste mesmo pensamento. Nesse sentido, acompanho as argutas observações de Schwarcz (1989), que, ao se debruçar sobre o mesmo tipo de fonte, afirma que o jornal "trabalha com e cria consensos, opera com dados num primeiro momento explícitos, e que na prática diária de repetições e reiterações tornam-se cada vez mais implícitos, reforçando-se enquanto verdades ou pressupostos intocáveis" (1989:248).

9 Lembre-se aqui que o primeiro momento desse novo ideário a respeito de praia é especificamente uma problemática carioca; autores de outras regiões parecem representar de outra forma seu litoral nessa época ainda de transição. O livro de Jorge Amado, Capitães de areia (1937), por exemplo, mostra a praia como o local de moradia para a população marginal da cidade de Salvador. Também é 
útil recordar uma canção dos anos 40 , salvo engano, que é de Dorival Caymmi - aliás, grande amigo de Amado -, e cujo refrão canta: "Eu não tenho onde morar/é por isso que eu moro na areia". Entrevê-se aí que a praia no Brasil, pelo menos até os anos 50 , em que se consolida Copacabana como seu ideal máximo, pode ser ainda um lugar de pobreza, também, e não apenas de donos de mansões de extravagantes estilos.

10 Não se pretende aqui entrar no tema da juventude; apenas indico as interessante abordagens de Machado Paes (1993), mais sociológica; e de Simon Frith (1981), especificamente sobre juventude e estilo musical. Para uma abordagem histórica, cf. Hobsbawm, 1991.

11 Abordando justamente o segmento econômico oposto ao que me refiro aqui, Hubert lafont (1983) examina a formação de turmas na juventude francesa de baixa renda.

12 Para esta tímida tentativa de interpretação, conto com o recurso aos trabalhos de Carvalho (1994 a, 1994b).

13 No entanto, uma outra interpretação do tom moreno se insinua desde os anos 50, por exemplo, nesta poesia de Vinícius de Moraes sobre as jovens que passeiam de bicicleta por Copacabana:
"Balada das meninas de bicicleta
Meninas de bicicleta
que faguciras pedalais
Quero ser vosso poeta!
O transitórias estátuas
Esfuziantes de azul
Louras com peles mulatas
Princesas da Zona Sul..."
(apud San Martini, 1992:90 - grifo meu)

14 Compreendo que o movimento de mulheres em busca de emancipação em vários niveis não nasce nos anos 60 , porém se pode dizer que o feminismo enquanto teoria e prática emerge, sim, nesse momento, a partir de pré-condições como a invenção da pílula anticoncepcional, que liberta a mulher da gravidez compulsória e um arranjo novo no mercado de trabalho mundial do pós-guerra.

15 É interessante notar que a própria disposição geográfica de Ipanema e Copacabana pode abranger esta atitude mental de considerar a primeira uma espécie de "posto avançado" da segunda.

16 Em 1980, a população do Rio era de 5.090 .700 habitantes, segundo o Anuário Estatístico da Cidade do Rio de Janeiro - 1990. 
